Jurnal Akuntansi dan Bisnis : Jurnal Program Studi Akuntansi 7 (1) Mei 2021

ISSN 2443-3071 (Print) ISSN 2503-0337 (Online)

DOI: $10.31289 / j a b . V 7 i 1.4454$

JURNAL AKUNTANSI DAN BISNIS

Jurnal Program Studi Akuntansi

Available online http://ojs.uma.ac.id/index.php/iurnalakundanbisnis

\title{
Do Regional Election and Presidential Election Affect Stock Exchange? An Event Study in the Indonesian Stock Exchange
}

\begin{abstract}
Khanifah'), Agus Triyani1) \& Suhita Whini setyahuni2)*
1)Fakultas Ekonomi, Jurusan Akuntansi, Universitas Wahid Hasyim Semarang, Indonesia

2) Fakultas Ekonomi, Jurusan Akuntansi, Universitas Dian Nuswantoro Semarang, Indonesia

*Coresponding Email: khanifah@unwahas.ac.id

Abstract

The 2018 simultaneous regional election in Indonesia is something new in the events of democratic politics in Indonesia. The events of the 2018 simultaneous regional election is one of the important events in 2018 that can cause a reaction of capital market to these events. This study aims to examine how the capital market reacts to the simultaneous regional elections in 2018 and presidential elections in 2019, by looking at the differences in the preceding and following periods based on 2 variables, namely abnormal return and trading volume activity. The sample in this study were 30 companies listed in the Indonesian Stock Exchange during 30 periods from February through July 2018. Research Methode This study used an event study. One paired samples T test was used as a technique analysis. The means of each variable within eleven days period was compared. The period of observation is five days before the event, five days after the event, and one day on event day. Based on the results of the parametric statistical calculations, the paired sample t-test showed that there was no difference between the level of abnormal returns before and after the 2018 simultaneous regional elections. On the other hand, there was a difference between trading volume of activity before and after the 2018 simultaneous regional elections.
\end{abstract}

Keywords : Capital Market; Event Study; Abnormal Retun and Trading Volume

How To Cite: Khanifah, Triyani, A., \& Setyahuni, S.W. (2021) Do Regional Election and Presidential Election Affect Stock Exchange? An Event Study in the Indonesian Stock Exchange. Jurnal Akuntansi dan Bisnis: Jurnal Program Studi Akuntansi, 7(1): 71-80. 


\section{INTRODUCTION}

Securities trading activities, especially activities on the stock exchange, as part of economic activity never escape from domestic and foreign influences. One of them is the political turmoil of political events that did not directly interfere with the stock market. However, this event is one of the information that is absorbed by capital market players and is used to obtain expected profits in the future. Ultimately the market will react to the information to strike a new equilibrium.

Currently, the capital market is an indicator of a country's economic assessment because companies that are entered or registered in the capital market are large and credible companies in the country concerned. With the capital market, investors can diversify their investments by forming portfolios according to the expected returns and risks they are willing to bear. The political situation will directly or indirectly affect the state of a country's economy. If the political situation is conducive, then the economy will tend to be stable and even likely to develop. Conversely, if the political situation of a country is not conducive, the economic situation will be disrupted, because investors do not dare to speculate on investment. Political events are often the main factor triggering fluctuations in stock prices on stock exchanges around the world. The increasingly important role of the capital market in economic and political activities makes the capital market more sensitive to various events in its surroundings, whether or not directly related to economic issues.

The first political event, the election of a regional head is a domestic political event which aims to elect the governor, regent and mayor which is carried out in accordance with the applicable law. Since the enactment of Law No. 32 of 2004 concerning Regional Government, regional head elections are part of Regional Autonomy and regional heads are elected directly by the people through the Election of Regional Heads and Deputy Regional Heads. The election process itself has gone through several changes. Regional Heads or Deputy Regional Heads who were initially elected directly by council members and simultaneously through Law No. 22/2014 were finally elected directly by the people and simultaneously through Law No.1 of 2015 which was later confirmed by the passing of Law No.1 of 2016.

The second political event, the election of the President and Vice President is one of the most important political events in this country, which aims to elect the leadership of the Republic of Indonesia which is carried out in accordance with the applicable laws. Investors have been eagerly awaiting information from the presidential and vice presidential elections in investing,because the leadership of the state will determine the policies of the Indonesian government in the next five years. Therefore, it is currently very attractive for investors to examine.

According to Wong \& Hooy (2020), firms are normally connected politically and this is a general phenomenon in developing countries. Therefore, information on political event may affect investors behaviour in deciding investment. Wong \& Hooy (2020) found that

That is why investors and potential investors may consider political information as an signal that can be used as one of a basis of investment decision making.

How quickly the information above can be absorbed by investors depends on the contents of the information on the regional and presidential elections. Information content can be in the form of good news content and bad news content (Tandelilin, 2014). More efficient a market is, the faster the information content can be reflected in stock prices in a 
market. Stock trading volume is a tool that can be used to see whether there is a market reaction to a particular event or not, to see the effect of political events on stock trading volume as seen from the related stock trading activity as measured by Trading Volume Activity (TVA). "Trading volume is number of shares stocks or indexs traded" (Jones et.al, 2009:447). "Trading volume is defined as the number shares bought and sold each day" (Abbondante, 2010:1). An active trading of a stock, that is, with a large trading volume, shows that the stock is favorite by investors, which means that the stock is quick to negotiate. There is a possibility that the dealer will change his share ownership when the stock trading gets higher or the dealer will not need to hold shares in an amount for too long. Trading volume will reduce the cost of owning shares, thereby lowering the spread. Thus, the more active the trading of a stock is or the greater the trading volume of a share, the lower the cost of ownership of the shares, which means that it will narrow the bid-ask for the share distribution.

To find out whether regional and presidential election activities can affect the volume of stock trading, we employedpaired sample t-test by comparing the means of the abnormal return and Trading Volume Activity (TVA).Political information, especially the regional and presidential elections are said to have an impact on the volume of stock trading, if there is a significant difference on the TVA prior the elections and TVA over the elections.

Several event studies that have been conducted to analyze the reaction of the Indonesian capital market to domestic economic events have proven that these events have relevant information content for capital market players, hence the market reacts to the information. Research conducted by Pratama et al. (2015)on the reaction of the Indonesian capital market to political events, concluded that there is a difference in the average value of stock trading volume. Research based on event studies, especially for daily periods such as Pilkada and Pilpres, requires issuers that are liquid in other words to have a large capitalization so that the effect of an event can be measured immediately and relatively more accurately (Santoso \& Sri Artini, 2015). IDX30 index shares are stocks that are actively traded on the IDX. IDX30 Index shares are selected from stocks that are included in the LQ45 index calculation in the same period and taking into account their transaction value activities. Therefore, IDX30 shares were chosen as the object of the company under study.

This research is an event study, which analyze the relationship between abnormal returns and trading volume activity with the events of the 2018 regional election and the 2019 Presidential Election. This study aims to assess the strength of the information content of an event on stock trading activities in the capital market. On the one hand, this study want to observe the reaction of the capital market participants to an event in the form of intervention from stakeholders regarding policies that must be decided in reducing the panic that occurs in the capital market.

This study provide a new insight on how the market participants react to the political information through the change of trading volume activity. Past studies mostly used abnormal return to observe the reaction of capital market to the issuance of information, especially those related to political events (Ahmed, 2017; Sajid Nazir, Younus, Kaleem, \& Anwar, 2014; Wong \& Hooy, 2020). By using two different indicators, we can determine factors that drive the reaction of the capital market during election events more precisely. 
Most scholars have investigated the reaction of capital market participants to the issuance of information. The existing studies mostly focus on events related to internal company such as earning announcement, dividen announcement, merger and acquisition announcement, and stock split. There are still a few studies that focus on external events such as macroeconomic events, changes in exchange rates, interest rates, or economic policies set by the government.Meidawati \& Harimawan (2004)conducted research on the 2004 Legislative Election. Indicators used include stock trading volume, abnormal return, and event studies. The results of his research show that there are differences in the average value of stock trading volume in the period before and after the 2004 Legislative Election events.

Islami \& Sarwoko (2012)examined the reaction of capital market on Sri Mulyani's resignation from her position as Finance Minister in 2010. The indicators used were abnormal return, TVA and SRV. They found that there was a significant abnormal return and TVA at the time of the announcement of the resignation of the Minister of Finance Sri Mulyani. Meanwhile, the SRV was not significant at the time of Finance Minister Sri Mulyani's announcement of the resignation.

Jange (2017) investigated capital market's response on regional election in 2015 and 2017. He used stock trading volume and abnormal volume as indicators. The results showed that there was an abnormal return in the 2015 and 2017 simultaneous regional elections. Meanwhile, there was no difference in stock prices and stock trading volume activity in the banking sector before and after the 2015 and 2017 regional elections.

Other study was conducted by Adila Nurheriyani (2014),who examined whether Presidential Inauguration will be reacted by the market participants or not. She compared the abnormal return and TVA before the inauguration and after the inauguration. She found that there was a significant difference in TVA during the inaugration's period. The other finding, however, proved that there was no difference on abnormal return in the period of inauguration.

The 2018 simultaneous regional election events are events that can indirectly affect stock trading activities on the Indonesia Stock Exchange. Furthermore, the information contained in these events can be used as consideration for investors in making investment decisions. Information regarding regional elections can be a positive signal for investors, especially related to better policy and bureaucracy due to the change of regional head. The reaction of the capital market to the 2018 simultaneous regional elections can be reflectedin the change of share prices on the Indonesia Stock Exchange. Changes in stock prices will result in differences in the average abnormal return before and after the 2018 simultaneous regional elections. Based on the reasons that have been explained, therefore, the first hypothesis is proposed as follows :

$\mathrm{H}_{1}$ : There is a difference in the average abnormal return of the IDX30 stocks prior the 2018 regional elections and the average abnormal return of the IDX30 stocks over the elections.

The reaction of the capital market to the simultaneous regional elections in 2018 can also be indicated by changes in stock trading volume activity. If the number of shares changes duringthe simultaneous regional elections in 2018, it will affect the stock price or stock return. Changes in stock trading volume activity will result in a significant difference in the average trading volume activity before and after the simultaneous regional elections in 2018. Thus, the second hypothesis is proposed as follows : 
$\mathrm{H}_{2}$ : There is a difference in the average stocks's trading volume of the IDX30 stocks prior the 2018 regional elections and the average stocks's trading volume of the IDX30 stocks after the elections.

Economic, social and political events that occur in a country can affect the the opportunity for companies to generate profits through a signal that is provided by the information. Hence, investors will recalculate the price of the shares they are trading based on expected returns with risks borne by investors. The changes in stock trading volume activity is a signal that capital market participants react the information of 2019 Presidential Election. If the number of shares changes before and after the 2019 Presidential Election, it will affect the stock price or stock return. Changes in stock trading volume activity will result in a significant difference in the average trading volume activity before and after the 2019 Presidential Election. Based on that reasons, the third hypothesis is written as follows :

$\mathrm{H}_{3}$ : There is a difference in the average trading volume of stocks that are issued in the IDX30 index pre election and the average stocks volume post the election.

The 2019 Presidential Election can be reacted by market participants, if the information have a content.Information regarding Presidential Election is an important aspect for prospective investors and may become a positive signal for them. If market participants react to information on Presidential Election, there is a change in volume of stocks trading. Changes in stock trading volume activity will result in a significant difference in the average trading volume activity in pre-election and over the 2019 Presidential Election. Hence, the last hypothesis is proposed as follows :

$\mathrm{H}_{4}$ : There is a difference between the average trading volume activity of stocks that are issued in the IDX30 index before the 2019 Presidential election and the average trading volume activity after the election.

\section{RESEARCH METHODS}

The population in this study were all companies listed on the Indonesian Stock Exchange. Meanwhile, the samples taken were companies listed in the IDX30 index for the period February to July 2018 and February to July 2019, therefore, total samples used in this study were 30 companies. This period was choosen according to the period of the simultaneous regional election events on 27 June 2018 and the presidentials elections. The IDX30 index is an index consisting of 30 stocks whose constituents are selected from the constituents of the LQ45 index. The LQ45 index constituents were chosen because the current LQ45 index is able to describe the performance of stocks with high liquidity and large market capitalization. The event period taken is from five days of stock trading before the event ( $t-5$ to $t-1)$ and five days of stock trading after the event $(t+1$ to $t+5)$. The total period of observation was eleven days, which was taken quite shortly after the general elections, which was aimed to prevent the effect of the issuance of other information. On the one hand, the market reaction is expected to be seen during this period. 


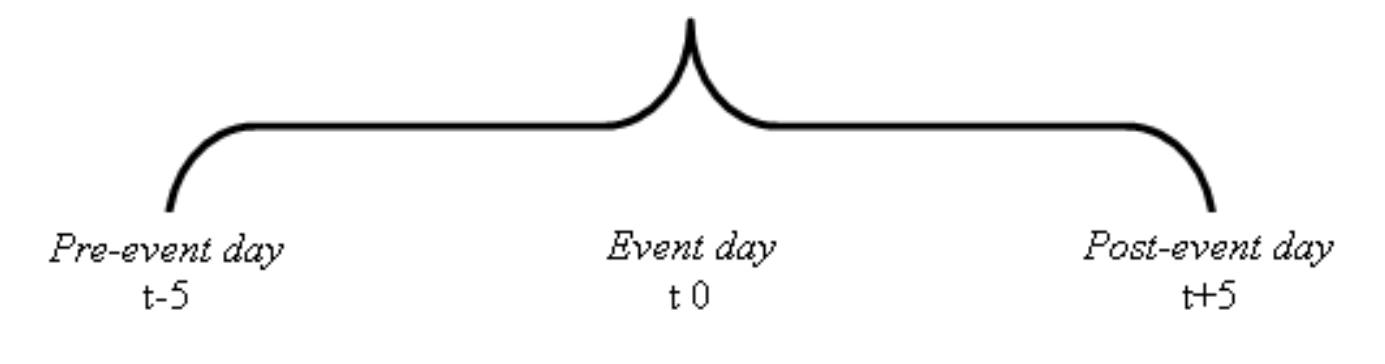

Figure 1. Research Period

Independent variables used in this study were abnormal return and trading volume activity. Abnormal return was measured using the difference between the actual return and the expected return (Hartono, 2009). The equation is written as follows:

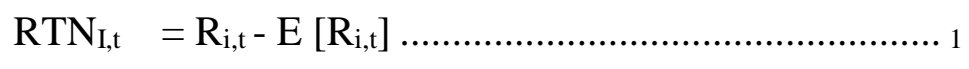

Where:

$\mathrm{RTNI}_{\mathrm{I}, \mathrm{t}}=$ Abnormal returnof company $\mathrm{i}$ at the event $\mathrm{t}$

$\mathrm{R}_{\mathrm{i}, \mathrm{t}} \quad=$ Actual return of company iat the event $\mathrm{t}$.

$E\left[R_{i, t}\right]=$ expected return of company I at the event $t$.

Trading volume activity is an instrument that can be used to observe the reaction of capital market participants on the issuance of information, which have content, through the change of stocks trading volume(Adila Nurheriyani, 2014). The following equation is used to measure trading volume activity:

TVA $_{i, t}=\frac{\sum \text { shares sold of company i at time } t}{\text { EOutstanding shares of company i at time } t} \ldots . .2$

This study is an event study, which want to explore the change of stocks return that occurs around the issuance of certain information. The event window used in this study are five days before the election date and five days after the election date, namely on April 10 to April 25 2019.The analysis technique applied in this study was one sample paired t-test, which used to test the diffference between abnormal return and TVA during the regional and presidential elections.

\section{RESULTS AND DISCUSSION}

The descriptive statistics of 30 samples are presented in table 1. From the table, it can inferred that the average of abnormal return before the presidential election was 0.00 , while the average after the elections was 0.00 . The minimum and maximum of abnormal return before the presidential election were -0.02 and 0.02 respectively. Furthermore, the abnormal return after the elections had a minimum value -0.03 and maximum value 0.03 , the descriptive statistics of trading volume activity for both before and after the elections showed a similar value, namely 0.00 .

The standar deviation of abnormal return before the presidential election was 0.01 , which had the same value for post-election. It indicated that there was a low level of abnormal return among 30 companies iin the IDX30 index. A similar condition also found 
in the trading volume activity, with 0.00 standar deviation for both before and after the presidential election. It can also be inferred that trading volume activity had no difference in both conditions.

Table 1. Descriptive Statistics

\begin{tabular}{lcccc}
\hline \multirow{2}{*}{ Descriptive Statistics } & \multicolumn{2}{c}{ Abnormal Return } & \multicolumn{2}{c}{ Trading Volume Activity } \\
\cline { 2 - 5 } & Before & After & Before & After \\
\hline Minimum & -0.02 & -0.03 & 0.00 & 0.00 \\
Maximum & 0.02 & 0.03 & 0.00 & 0.00 \\
Mean & 0.00 & 0.00 & 0.00 & 0.00 \\
Standar Deviation & 0.01 & 0.01 & 0.00 & 0.00 \\
\hline
\end{tabular}

Source: The Processed Secondary Data (2020)

Table 2 presented the result of data analysis. Before the one sample paired t-test was applied, we tested the normality through Kolmogorov-Smirnov test. The KolmogorovSmirnov test and Levene test's results show that both abnormal return and TVA are normally distributed and have homogen variance either before or after the 2018 regional elections.Based on the result, the significance value of paired t-test is 0.225 , which is not significant at 0.05 level. We can infer that hypothesis one can not be supported, which means there is no difference between the average abnormal return before the 2018 simultaneous regional elections and the average abnormal return after the elections.

Table 2. Data Analysis

\begin{tabular}{|c|c|c|c|c|}
\hline \multirow{2}{*}{ Variables } & \multicolumn{2}{|c|}{ Kolmogorov-Smirnov } & \multirow{2}{*}{ Levene Test } & \multirow{2}{*}{ Paired T-tes } \\
\hline & Before & After & & \\
\hline \multicolumn{5}{|c|}{ The 2018 Regional Elections } \\
\hline Abnormal Return & 0.200 & 0.189 & 0.876 & 0.225 \\
\hline Trading Volume Activity & 0.134 & 0.104 & 0.270 & $0.00^{*}$ \\
\hline \multicolumn{5}{|c|}{ The 2019 Presidential Election } \\
\hline Abnormal Return & 0.200 & 0.109 & 0.644 & 0.160 \\
\hline Trading Volume Activity & 0.177 & 0.187 & 0.270 & $0.00 *$ \\
\hline *Significant at 0.05 level & & & & \\
\hline
\end{tabular}

This findingis consistent with research conducted by Luhur (2010) who found that there was no difference in the average abnormal return and the average trading volume (TVA) both before and after the event study of the presidential and vice presidential elections on July 8, 2009. On the one hand, other research on the difference between abnormal return during the 2014 Legislative Election, which was conducted by Suarjana (2014)also found the similar finding. He found that there was no significant difference between the abnormal return before the the 2014 Legislative Election event and the abnormal return after event.

In this simultaneous Pilkada event, investors do not consider the political event as an important aspect that will affect stock prices. Political information is not considered as a positive signal by investors, as it is only an event which do not affect the company's performance directly. Hence, investors tend to take wait and see actions in the market. This action is taken by investors because they do not want to take risks too quickly in making decisions from external information. 
The result of paired t-test of trading volume activity during the 2018 regional elections is 0.00 , which is significant at 0.05 level. The second hypothesis, therefore, can be supported by the empirical evidence. It means that there is a difference between the average trading volume before the 2018 regional elections and the average trading volume after the events.

According to Colón-De-Armas, Rodriguez, \& Romero (2017), the reaction of market participants on the issuance of political information might be caused by the increase of investor's optimism. Investors believe which president candidate will win the election, hence they also revise their expectation around these events. Investors tend to be optimistic the offensive power in government, but they become pessimistic if there is continuity in power of government (Colón-De-Armas et al., 2017). Hence, the re-election of president and vice president is the process to re-elect the power, which may discontinue the prior power. Therefore, the issuance of this information can drive a market reaction.

Hypothesis 3 is rejected due to the significance value of paired t-test is 0.160 , which is not significant at 0.05 level. It means that there is no difference between the average of abnormal return before the 2019 Presidential Election and the average of abnormal return after the election. It prove that investors do not consider political information, especially information on presidential election as an important. Investors were not affected by the 2019 presidential election. It because the information on presidential elections had been anticipated by investors. The result of the presidential election also had been predicted, hence the information might be reacted by investors before it was released.Furthermore, The results of this event had previously been predictable, namely by seeking information first through online media, social media or other media that provide information with fast and current updates. Given the current rapid development of information technology, it is not difficult for investors to obtain information that can support their investment decisions.

Our finding is consistent with research conducted bySantoso \& Sri Artini (2015), who found that there were no difference between abnormal return before the 2014 legislative election and abnormal return after the event. As stated by Hall, Karadas, \& Schlosky (2017), investors take no advantage on political information, or they might had reacted to the issuance of the information prior the election. Therefore, there is no more reaction during the general election.

Hypothesis 4 can be supported by the empirical evidence, which have a significant paired ttest's result $(0.00, \mathrm{p}<0.05)$. It means that the average TVA before the 2019 Presidential Election is different from those after the election. This finding is different fromJange (2017), who found none difference on the average TVA during the simultaneous regional elections in 2015 and 2017.The difference on the average TVA prove that investors take a chance for making profit and avoid risk in an uncertain condition during political event, especially the presidential election.

Based on the result, information on the simultaneous regional elections do not provide positive signal for neither investors nor potential investors. Information can be said having content, if it can be used a basis for decision making. Market will react to the issuance of the information that have content. Sajid Nazir et al., (2014) stated that in the inefficient market, information can be absorbed lately. Market reaction of the certain information proved that information released is slightly important, hence the reaction of the market participants is only found in the change of the average TVA, but not in the average abnormal return. 


\section{CONCLUSIONS}

Information can be considered by capital market participants as a basis for decision making, if it has content. Information is divided into two forms, which are good news and bad news. How quickly market participants absorb the information depend on the efficiency of the market. This study intends to examine the effect of regional elections and presidential election on both abnormal return and trading volume activity.

We find several findings, which can be summarized into four main parts. First, we do not find a difference on the average abnormal return during the 2018 simultaneous regional elections. Second, there is a difference on the average TVA both before and after the 2018 regional elections. Third, there is no difference on the average abnormal return during the 2019 presidential election. Last, we find that the average TVA before the 2019 presidential elections is different from the average TVA after the election.

Our result provide a new insight for academics, policy makers, and investors. For academics, we provide an empirically evidence on the reaction of market participants during political events based on the signalling theory. For policy makers, this study can be considered as a basis for making regulation regarding stock market. For investors, we provide an insight, especially on how do market participants behave during political events.

Our research, however, have several limitations. First, we only focused on the general election to observe the effect of political events on stock market. Hence, the effect of external information on the stock market had not explored deeply yet. Second, we only used one model, namely market adjusted model, which was developed by Brown \& Warner (1985). Third, we only focused on abnormal return and trading volume activity as the market's indicators.

Future research need to explore more closely to which degree the difference of capital market participants in giving respond on political events. To provide more comprehensive picture regarding the effect of external information on stock markets, future research can adopt a bigger scale of political information, such as the change of legislative. Other valuation models also can be used to assess the degree of market's reaction on political information, such as maket model and means adjusted model. Lastly, other indicators such as, bid-ask spread can be employed, in order to examine the reaction of market participants more deeply.

\section{REFERENCES}

Adila Nurheriyani. (2014). Analisis Volume Perdagangan dan Abnormal Return Saham Sebelum dan Sesudah Pelantikan Presiden dan Wakil Presiden. Jurnal Ekonomi Dan Kewirausahaan, 15(1), 1-5. https://doi.org/10.1007/s13398-014-0173-7.2

Ahmed, W. M. A. (2017). The impact of political regime changes on stock prices: the case of Egypt. In International Journal of Emerging Markets (Vol. 12). https://doi.org/10.1108/IJoEM-12-2015-0258

Ashraf, A., Hassan, M. K., Abbas, K., \& Zaman, Q. U. (2020). Do firms harvest from political connections during general elections? Case of Pakistan. Journal of Financial Crime, 27(1), 258-273. https://doi.org/10.1108/JFC-02-2019-0022

Brown, S. J., \& Warner, J. B. (1985). Using Daily Stock Returns. The Case of Event Studies. Journal of FInancial Economics, 14, 3-31.

Colón-De-Armas, C., Rodriguez, J., \& Romero, H. (2017). Investor sentiment and US presidential elections. Review of Behavioral Finance, 9(3), 227-241. https://doi.org/10.1108/RBF-02-2016-0003 
Khanifah, Agus Triyani \& suhita whini Setyahuni, Do Regional Election and Presidential Election Affect Stock

Fama, E. F. (1970). Efficient Capital Markets: II. The Journal of Finance, 46(5), 1575-1617. https://doi.org/10.2307/2328565

Hall, J. C., Karadas, S., \& Schlosky, M. T. T. (2017). Abnormal returns from joining Congress? Evidence from new members. Journal of Financial Economic Policy, 9(4), 450-474. https://doi.org/10.1108/JFEP-122016-0095

Hartono, J. (2009). Teori Portofolio dan Analisis Investasi. Yogyakarta: BPFE UGM-Yogyakarta.

Hin, L. T. (2001). Bursa Saham (1st ed.). Jakarta: Gramedia Pustaka Utama.

Islami, L. N., \& Sarwoko, E. (2012). Reaksi Pasar Modal Indonesia Terhadap Pergantian Menteri Keuangan ( Event Study Saham Yang Terdaftar Di Bei ). Modernisasi, 8(1), 44-67. Retrieved from http://ejournal.unikama.ac.id/index.php/JEKO/article/view/206

Jange, B. (2017). Jurnal Ilmu Komputer dan Bisnis, Volume 8, Nomor 1, Mei 2017. Jurnal Ilmu Komputer Dan Bisnis, 8(Sunjana 2010), 1841-1846.

Luhur, S. (2010). Reaksi Pasar Modal Indonesia Seputar Pemilihan Umum 8 Juli 2009 Pada Saham LQ45. Jurnal Keuangan Dan Perbankan, 14(2).

Meidawati, N., \& Harimawan, M. (2004). Pengaruh Pemilihan Umum Legislatif Indonesia Tahun 2004 terhadap Return Saham dan Volume Perdagangan Saham LQ-45 di PT Bursa Efek Jakarta (BEJ). Sinergi, 7(1), 89-101. https://doi.org/10.20885/sinergi.vol7.iss1.art6

Pratama, I. G. B., Sinarwati, N. K., \& Dharmawan, N. A. S. (2015). Reaksi Pasar Modal Indonesia Terhadap Peristiwa Politik ( Event Study pada Peristiwa Pelantikan Joko Widodo Sebagai Presiden Republik Indonesia Ke-7 ). Jurnal Akuntansi Universitas Pendidikan Ganesha, 3(13), 1-11.

Sajid Nazir, M., Younus, H., Kaleem, A., \& Anwar, Z. (2014). Impact of political events on stock market returns: empirical evidence from Pakistan. Journal of Economic and Administrative Sciences, 30(1), 60-78. https://doi.org/10.1108/jeas-03-2013-0011

Santoso, H., \& Sri Artini, L. (2015). Reaksi Pasar Modal Indonesia Terhadap Pemilu Legislatif 2014 Pada Indeks Lq45 Di Bei. Jurnal Manajemen Universitas Udayana, 4(9), 255220.

Suarjana, I. W. (2014). Dampak Peristiwa Pemilu Legislatif 2014 Terhadap Perolehan Abnormal Return di Bursa Efek Indonesia. Jurnal Ilmu Manajemen, 4(2), 127-135.

Tandelilin, E. (2014). Portofolio dan Investasi. Yogyakarta: Kanisius.

Wong, W. Y., \& Hooy, C. W. (2020). Market response towards different types of politically connected firms during political events: evidence from Malaysia. International Journal of Managerial Finance. https://doi.org/10.1108/IJMF-09-2019-0331 